\title{
Going Quarterly!
}

Wim Vandekerckhove ${ }^{1}$

Published online: 20 February 2020

(C) Springer Nature Switzerland AG 2020

\section{Abstract}

This article is the editorial to issue 1 of volume 19 of this journal. It announces the journal is now a quarterly publication and comments on changes to the editorial board.

I write this editorial as a happy editor-in-chief. Perhaps 'happy' is not the most obvious attribute one would ascribe to a philosopher but then again, philosophy of management is also not the most obvious area of life for philosophical inquiry.

And yet ... the joy I have now stems from being in a position to write the first editorial of this journal as a quarterly publication! Both the authorship as well as the readership of the journal have grown, up to the point where we decided to make the leap to more frequent issues - four times a year from now on. The inclusion of our journal in the Emerging Sources Citation Index (ESCI - Web of science) and in the SCOPUS databases have undoubtedly helped to get to this point but it is mostly the authors who submit their manuscripts, the reviewers who help to develop the articles, and also the editors, whose hard work over the past years have brought us here. I thank all of them here, in this celebratory editorial.

Moving to a quarterly frequency is in that sense a point of demarcation, which serves to make tangible the efforts of many people. A demarcation also allows to start a new phase. For this journal, that start of a new phase comes with a refreshed editorial board. As I have experienced it, the list of names that make up an editorial board is somewhat a misrepresentation of how a journal really comes to be what it is. First, board lists include names of scholars who together can be seen to constitute a field of scholarship, of which the journal functions as a publication outlet. Their support indicates the main intellectual direction of a journal. Second, board lists include names of people who advise on decisions an editor-in-chief needs to take about specific projects related to the journal, such as whether or not to go ahead with a special issue proposal. Third, editorial board lists also include the names of people who frequently act as reviewers. Now, the actual set of people who perform these functions is always in flux and thus, an editorial board list is a mere approximation of the many intellectual interactions which a journal is a reification of.

Wim Vandekerckhove

w.vandekerckhove@greenwich.ac.uk 
It struck me some time ago that our list was no longer approximating the group of people who editorially produce the journal. Hence the editorial board was revised to better reflect our reviewers, advisors and supporters. This has resulted in a more diverse editorial board, in three ways: geographical affiliation, world view, and gender. Of course this is the result of a deliberate attempt. Yet the attempt was to include people who actually do a lot of the reviews; the attempt was to include national affiliations in congruence with our authors' affiliations. To see diversity in the outcome of these attempts is heartening for someone who tries to make a career from be curious, surprised and precise.

There is a specific group of editorial board members I have not mentioned yet. They are listed as 'executive editors' and take a pro-active (and often entrepreneurial) role in shaping the journal's scope and reach. Some changes have happened here too. Last year, Cristina Neesham joined the team. She is Reader in Business Ethics and CSR at Newcastle University Business School. Cristina plays a leading role in running workshops and paper tracks on Philosophy of Management at the Academy of Management and EGOS conferences. Starting this volume, Eva Tsahuridu has also joined the executive editors team. Eva is Associate Professor and Industry Fellow at RMIT University Melbourne. As an ethics and policy expert, Eva has firsthand knowledge of how philosophical inquiry can better management practice and professionalism. I welcome both Cristina and Eva to their prominent role in carrying the journal.

Last, but not least, I thank two longstanding executive editors who will shortly be taking a different role. For more than a decade, Mark Dibben and Frits Schipper have been instrumental in nurturing the field of philosophy of management, in particular through their collaboration in developing our Philosophy of Management conference series, often held at St Anne's College, University of Oxford, and their initiatives to build this journal. I thank them for being inspiring scholars, dedicated editors, and warm friends. I hope the journal will continue to benefit from their wisdom and advice.

Wim Vandekerckhove holds a Phd in Moral Sciences from Ghent University. He is now Reader in Business Ethics at the University of Greenwich, and is co-director of CREW (Centre for Research on Employment and Work). 